\title{
WOLNOŚĆ I SWOBODA TWÓRCZA A ZARZUT AUTOPLAGIATU W UTWORZE NAUKOWYM
}

\begin{abstract}
Współczesne kodeksy wartości, funkcjonujące w obszarze nauki, a dotyczące autorów dzieł naukowych coraz częściej definiują autoplagiat jako nadużycie ze strony twórcy, mające wywołać nieprawdziwe przekonanie o kreatywności i pomysłowości twórców. Czy każde powtórne wykorzystanie swojej twórczości w nowo kreowanym dziele jest naganne z punktu widzenia zarówno prawa, jak i etyki? W treści wskazano zależności prawne między autorem a jego utworem, przywołano konstytucyjne znaczenie wolności twórczej, która w istocie swej rozumiana jest jako jedno z podstawowych praw, o czym traktują również przepisy aktów międzynarodowych. Postawiono pytanie: czy jest to prawo nieograniczone? Zaprezentowano argumenty przeczące założeniu, że swoboda tworzenia ma charakter ius absolutum. Gdzie szukać granic wolności autora, w kontekście cywilistycznego władztwa nad utworem? W wolności i prawach innych ludzi, ale także w definicji legalnej utworu. Tam bowiem pojawiają sie elementy konieczne do nazwania wytworu intelektualnego dziełem - w rozumieniu prawa autorskiego. Wolność nauki jest założeniem każdego demokratycznego porządku. Ale czy nauka, skupiająca w sobie niesamowitą moc oddziaływania na rzeczywistość podlega ograniczeniom? Artykuł potwierdza tak postawioną tezę.

W prezentowanym tekście podjęto próbę znalezienia odpowiedzi na pytanie, czy autoplagiat jest rzeczywistym problemem nauki, czy sztucznie wykreowanym, czy zarzut autoplagiatu nie narusza wolności i swobody twórczej, czy nie stanowi swoistego ograniczenia władztwa nad utworem. Zwrócono uwagę na równoważny problem, jakim jest - w szczególności w dziedzinach humanistycznych tworzenie kreacji intelektualnych zbudowanych w głównej mierze na zapożyczeniach z cudzej, ale i własnej twórczości, ,ubranych” w prawidłową formę cytatu czy też autocytatu, w których coraz trudniej dopatrzyć się oryginalności.
\end{abstract}

Słowa kluczowe: autoplagiat, plagiat, twórca, dzieło naukowe, oryginalność.

\section{WPROWADZENIE}

Wielokrotne wykorzystanie swojej twórczości (w całości lub fragmentach) w nowopowstającym utworze, publikowanie tego samego dzieła w różnych wydawnictwach (po „kosmetycznych” zmianach tytułu, treści) traktowane jest w środowisku twórców, jako nieetyczne i naganne nadużycie. Taki sposób działania nie znajduje usprawiedliwienia wśród tych, którzy dopatrują się w nim nieudolnej próby przekonania odbiorców, że nowopowstałe dzieło jest wynikiem kreacji, talentu i pomysłowości autora. I chociaż przepisy prawa

\footnotetext{
${ }^{1}$ Mgr Elżbieta Kosior, prokurator Prokuratury Okręgowej w Rzeszowie w stanie spoczynku, asystent w Katedrze Prawa i Administracji, Wydział Zarządzania Politechniki Rzeszowskiej im. I. Łukasiewicza, ul. Powstańców Warszawy 10, 35-959 Rzeszów; e-mail: ekosior@ prz.edu.pl Elżbieta Kosior, MA, Faculty of Management, Rzeszow University of Technology, Poland - Rzeszow; e-mail: ekosior@prz.edu.pl
} 
autorskiego $^{2}$ nie wprowadzają kryterium nowości do definicji utworu, jak czyni to prawo własności przemysłowej ${ }^{3}$ (vide: wynalazek, wzór użytkowy i inne) to niewątpliwie istotą utworu jest jego oryginalność, traktowana, jako nowość subiektywna ${ }^{4}$.

Nieprawdziwym byłoby jednak twierdzenie, że każdorazowe wykorzystanie w tworzonym dziele efektów swojej dotychczasowej twórczości wpłynie na pozbawienie utworu cechy oryginalności. Takiemu założeniu przeczy uznawana w praktyce i nauce możliwość odwołania się do swojej twórczości poprzez skorzystanie z prawa cytatu ${ }^{5}$. Niemniej jednak nadużywanie prawa cytatu, a w omawianym zagadnieniu swoistego ,autocytatu” może również być przyczyną oceny, że wytwór intelektualny naszego umysłu nie spełnia wymagań ustawowych, bowiem pozbawiony jest waloru kreatywności.

Wykorzystanie własnej twórczości, efektów samodzielnego i oryginalnego konceptu w nowych dziełach, bez wskazania źródeł, utożsamiane jest z działaniami nierzetelnymi i nieuczciwymi i definiowane jest jako autoplagiat. Nadużywanie prawa ,autocytatu”, a więc odwoływanie się do swojej twórczości, ze wskazaniem źródła może uczynić nasze dzieło bezwartościowym w rozumieniu definicji ustawowej utworu, kiedy przekroczymy umownie przyjęte (w powszechnym rozumieniu) granice jakościowe i ilościowe dopuszczalnego wykorzystania efektów swojej dotychczasowej pracy twórczej.

Krytyczna ocena opisanych zachowań uwidacznia się w szczególności w działalności naukowej, w której udokumentowany dorobek naukowy jest kryterium awansu naukowego $^{6}$, a także przy tworzeniu pracy magisterskiej, będącej kontynuacją badań, których wyniki zaprezentowano we wcześniejszej pracy licencjackiej.

Z punktu widzenia twórcy, chcącego wykorzystać swój dotychczasowy dorobek naukowy w celu opracowania kolejnego dzieła, pojawiają się wątpliwości, co do zakresu i formy, w jakich jest to dopuszczalne. Wszak prawo własności, w tym prawo do stworzonego dzieła wydaje się być wyjątkowo szerokie, ale czy nieograniczone? Konstrukcja ochrony własności, w tym własności intelektualnej, wyrażona przez ustrojodawcę przede wszystkim w art. 21 i 64 Konstytucji RP, zawiera w sobie z jednej strony obowiązek stworzenia przez Państwo odpowiednich instrumentów prawnych zapewniających ową ochronę, z drugiej zaś gwarancję powstrzymywania się od rozwiązań pozaustawowych, które miałyby ją ograniczać ${ }^{7}$.

I chociaż na przestrzeni lat zmieniała się zarówno linia orzecznicza Trybunału Konstytucyjnego jak i doktryna, w traktowaniu efektów pracy twórczej człowieka - jednym razem w kategoriach prawa własności, kolejnym zaś w kategoriach innych praw majątkowych to

${ }^{2}$ Ustawa z dnia 4 lutego 1994 roku o prawie autorskim i prawach pokrewnych, art. 1 (tekst jedn. Dz.U. z 2017 r., poz. 880).

${ }^{3}$ Ustawa z dnia 30 czerwca 2000 roku - Prawo własności przemysłowej, art. 24 (tekst jedn. Dz.U. z 2017 r., poz. 776).

4 J. Sieńczyło-Chlabicz, J. Banasiuk, Pojęcie i istota zjawiska autoplagiatu w twórczości naukowej „Państwo i Prawo” 2012, nr 3, s. 8.

5 Ustawa z dnia 4 lutego 1994 roku o prawie autorskim i prawach pokrewnych, art. 29.

${ }^{6}$ Ustawa z dnia 14 marca 2003 r. o stopniach naukowych i tytule naukowym oraz o stopniach i tytule w zakresie sztuki (tekst jedn. Dz.U. z 2017 r., poz. 1789).

7 Artykuł 21 ust. 1 Konstytucji RP „Rzeczpospolita Polska chroni własność i prawo dziedziczenia”. Art. 64 Konstytucji RP „1. Każdy ma prawo do własności, innych praw majątkowych oraz prawo dziedziczenia. 2. Własność, inne prawa majątkowe oraz prawo dziedziczenia podlegają równej dla wszystkich ochronie prawnej. 3. Własność może być ograniczona tylko w drodze ustawy i tylko w zakresie, w jakim nie narusza ona istoty prawa własności." 
nie ma wątpliwości, że wytwór intelektu definiowany, jako utwór czy projekt racjonalizatorski należy do sfery konstytucyjnie chronionej ${ }^{8}$.

Twórczość z kolei wiąże się nierozerwalnie z pojęciem wolności, swobodą wyrażania, „sztuka jest córką wolności i chce być posłuszna jedynie konieczności duchowej” pisał Friedrich Schiller w „Listach o estetycznym wychowaniu człowieka”. Stąd też wolności twórczej Konstytucja również zapewniła ochronę ${ }^{10}$. Ale czy wolność twórcza jest prawem absolutnym? Czy prawa osobiste i majątkowe do własnego dzieła, będącego wyrazem swobody twórczej podlegają ograniczeniom? Czy takim ograniczeniem, wynikającym zarówno z definicji samego utworu jak i norm etycznych będzie możliwość narażenia się na zarzut autoplagiatu, dyskwalifikujący autora pracy dyplomowej, utworu naukowego? Jaki jest zakres chronionego konstytucyjnie majątkowego prawa do dzieła i możliwość jego prawnego ograniczenia? Czy takie atrybuty własności jak skuteczność erga omnes, wyłączność władztwa, zbywalność, nieograniczoność w czasie są przynależne efektom pracy twórczej, w tym naukowej?

Próba udzielenia odpowiedzi na wyżej zadane i zbliżone pytania będzie zasadniczym celem niniejszego artykułu.

\section{TWÓRCA I JEGO DZIELO - PRAWNE ZALEŻNOŚCI}

W związku z tym, że w działalności twórczej pracowników naukowych, studentów uczelni wyższych zdecydowanie częściej mamy do czynienia z kreacją umysłu ludzkiego w rozumieniu Ustawy z 4 lutego 1994 roku O prawie autorskim i prawach pokrewnych, ochrona prawno-autorska i uprawnienia autora będą odniesieniem do dalszych rozważań. Nie można jednakowoż zapominać, że w zakres konwencyjnej definicji własności intelektualnej, użytej w art. 2 pkt "viii" Konwencji o Ustanowieniu Światowej Organizacji Własności Intelektualnej, podpisanej w Sztokholmie dnia 14 lipca 1967 roku ${ }^{11}$, wchodzą prawa odnoszące się nie tylko do dzieł literackich, artystycznych i naukowych, interpretacji i wykonań artystycznych, ale również do działalności ludzkiej w dziedzinie przemysłowej (wynalazki, wzory przemysłowe, odkrycia naukowe itd.).

Dzieło(utwór) i twórca(autor) to podstawowe pojęcia wyznaczające zakres przedmiotowy i podmiotowy prawa autorskiego. Aby rezultat pracy umysłowej człowieka zyskał miano dzieła i podlegał ochronie prawnej musi spełniać łącznie następujące przesłanki, określone przez ustawodawcę $\mathrm{w}$ art. 1 ust. 1 przywołanej ustawy:

- musi być przejawem działalności twórczej,

- posiadać indywidualny charakter,

- zostać ustalony w jakiejkolwiek postaci.

\footnotetext{
8 Por. wyrok Trybunału Konstytucyjnego z 22 czerwca 2015 roku, sygn. SK32/14, OTK-A 2015/6, poz. 84, Konstytucja Rzeczypospolitej Polskiej. Komentarz, pod red. L. Garlickiego, t. III, Warszawa 2003, art. 21 i 64, T. Dybowski, Ochrona prawa wtasności na tle konstytucyjnej koncepcji źródet prawa w orzecznictwie TK [w:] Trybunat Konstytucyjny. Księga XV-lecia, pod red. F. Rymarza, A. Jankiewicza, Warszawa 2001, s. 112

${ }^{9}$ F. Schiller, Listy o estetycznym wychowaniu człowieka, Pisma teoretyczne, Warszawa 2011, s. $43-44$.

${ }^{10}$ Art. 73 Konstytucji RP.

${ }^{11}$ Konwencja o Ustanowieniu Światowej Organizacji Własności Intelektualnej (Dz.U. z 1975 r., nr 9, poz. 49).
} 
Nie jest istotne natomiast przeznaczenie, wartość ani też sposób wyrażenia. Utwór to dobro niematerialne, utrwalone najczęściej na nośniku, stanowiącym dobro materialne $(\text { rzecz })^{12}$. Literatura przedmiotu i judykatura poświęciły wiele miejsca wyjaśnieniu pojęć definiujących utwór.

Już w wyroku z 5 marca 1971 r., I CR 593/70 (OSNC 1971, nr 12, poz. 212), a więc na gruncie ustawy z 10 lipca 1952 roku o prawie autorskim (Dz.U. z 1952 r., nr 34, poz. 234) Sąd Najwyższy zwrócił uwagę, że „o powstaniu prawa autorskiego nie decyduje stopień wartości opracowanego dzieła, gdyż nawet znaczeniowo niewielkie opracowania mogą stanowić przedmiot ochrony autorskiej, byleby cechował je element twórczości autora." Odwołując się do tego orzeczenia Sąd Najwyższy w 2006 roku, orzekł, że charakter twórczy utworu, jako jego immanentna cecha jest wyrazem pracy intelektualnej a nie chociażby pracy technicznej, polegającej na stosowaniu określonej wiedzy, przy użyciu określonych narzędzi. I tak jak efekty pracy technicznej są przewidywalne i powtarzalne, tak praca twórcza wiążę się z projekcją wyobraźni człowieka ${ }^{13}$. „Praca twórcza cechuje się, bowiem tym, że jej rezultat jest niepewny, toteż poświęcenie na nią określonego czasu wcale nie świadczy o uzyskaniu zamierzonych efektów w postaci stworzenia utworu" ${ }^{14}$.

Prawo autorskie nie uzależnia ochrony prawnej od spełnienia przesłanki nowości w znaczeniu przedmiotowym. Nowość nie jest kryterium wprowadzonym do definicji utworu. Niemniej jednak powtarzając za Sądem Najwyższym należy stwierdzić, że przejawem twórczego, a więc oryginalnego działania będzie tzw. nowość podmiotowa. Subiektywne przekonanie i deklarowanie twórcy, co do oryginalności stworzonego przez niego dzieła jest weryfikowalne ${ }^{15}$. Indywidualny charakter dzieła ma podkreślać jego związek z autorem, samodzielność a zarazem swobodę twórczą, ,kryteriami pomocnymi dla stwierdzenia cechy indywidualnego charakteru są istnienie swobodnej przestrzeni twórczej oraz jej efektywne wykorzystanie przez autora w trakcie tworzenia" ${ }^{16}$. Zdaniem Ryszarda Markiewicza nie można mówić o indywidualnych rezultatach pracy, które są na wskroś rutynowe ${ }^{17}$. Indywidualność obrazowana jest zarówno w orzecznictwie sądowym jak i w opisach przedstawicieli doktryny, jako „osobiste ujęcie (interpretacja, wizja)”, ,piętno osobiste”, ,wytwór indywidualnej myśli" 18 .

Z punktu widzenia złożoności problemu wydaje się, że najbardziej czytelna jest ostatnia przesłanka warunkująca istnienie utworu, czyli ustalenie dzieła, od którego rozpoczyna się ochrona autorskoprawna.

To nic innego jak moment uzewnętrznienia pracy twórczej, kiedy kreacja umysłu przybierze jakąkolwiek postać, choćby nietrwałą, jednak na tyle stałą, żeby treść i cechy utworu

12 Por. J. Barta, R. Markiewicz (red.), Ustawa o prawie autorskim i prawach pokrewnych, Komentarz, wyd. V, e-Lex 2011 (art. 1 i 52).

13 Wyrok SN z dnia 25 stycznia 2006 r., I CK 281/05, (OSNC 2006, nr 11, poz. 286).

14 Wyrok NSA z dnia 12 marca 2010 r., II FSK 1791/08, (LEX nr 595971).

15 Wyrok SN z dnia 22 czerwca 2010 r., IV CSK 359/09, (OSP 2011, z. 5, poz. 59).

${ }^{16}$ D. Flisak (red.), Prawo autorskie i prawa pokrewne. Komentarz e-LEX 2015 (art. 1).

${ }_{17}$ R. Markiewicz, Opinia prawna dot. pojęcia utworu oraz pojęcia dokumentu urzędowego materiatu urzędowego w rozumieniu polskiego prawa autorskiego, s. 5, http://www.informacjapubliczna. org.pl (dostęp 19 lutego 2017 r.).

${ }_{18}$ R.M. Sarbiński, M. Siciarek (red.), Prawo autorskie. Komentarz do wybranych przepisów (do art. 1, Działalność twórcza), e-LEX 2017. 
wywierały efekt artystyczny ${ }^{19}$. To uzewnętrznienie może przybierać dowolną formę od ustnej począwszy po formę wykorzystującą złożone środki wyrazu literackiego czy artystycznego.

Podmiotem prawa autorskiego jest twórca, może nim być wyłącznie osoba fizyczna, na co wskazuje istota procesu twórczego ${ }^{20}$. Stworzenie dzieła jest czynnością faktyczną, realną, nie zaś prawną. Zdolność tworzenia przypisana jest tylko człowiekowi. Stąd też uznaje się twórcę „,za genetycznie sprzężonego z utworem”21. Twórca wyposażony został w szereg praw, których suma zapewnia właściwą ochronę prawną.

Polski ustawodawca przyjął konstrukcję dualizmu uprawnień przysługujących twórcy, rozgraniczając osobiste prawa autorskie od majątkowych praw autorskich. Wyszególnione w art. 16 i 17 prawa autorskiego grupy praw stanowią odrębne unormowania, samodzielne i niezależne od siebie, realizujące wyznaczone przez ustawodawcę cele. Funkcją uprawnień osobistych, do których ustawa zalicza w szczególności prawo do:

- autorstwa utworu,

- oznaczenia utworu swoim imieniem i nazwiskiem, pseudonimem lub pozostania anonimowym,

- poszanowania integralności utworu(nienaruszalności formy i treści) oraz jego rzetelnego wykorzystania,

- decydowania o pierwszym publicznym udostępnieniu utworu,

- nadzorowania sposobu jego wykorzystania, jest zapewnienie i podkreślenie więzi twórcy z utworem.

Osobisty charakter tych uprawnień zadecydował o zakazie ich zbywania i nieograniczonej w czasie ochronie prawnej. Osobiste dobra autora chronione są za jego życia(stante vita) i po jego śmierci (post mortem).

Pozamaterialna więź twórcy z utworem, według koncepcji podawanej za rzymskim poetą Horacym, czyni autora dzieła nieśmiertelnym. Non omnis moriar (nie wszystek umrę), będę żył w moich dziełach, tak Horacy ujął ponadczasowość więzi autora z utworem $^{22}$.

Zgoła odmiennie prezentują się prawa majątkowe do utworu; zapewniają twórcy możliwość dysponowania dziełem i prawo do wynagrodzenia. W ramach dysponowania dziełem ustawodawca przyznaje autorowi wyłączne prawo do korzystania z niego i rozporządzania nim na wszystkich polach eksploatacji ${ }^{23}$. Oznacza to, że zgoda autora będzie warunkiem sine qua non do legalnego korzystania przez innych z jego utworu. Zgoda autora przyjmuje zazwyczaj umowną postać licencji bądź przeniesienia praw. Konsekwencją tych czynności faktycznych będzie prawo autora do wynagrodzenia ${ }^{24}$. Majątkowe prawa autorskie korzystają z ograniczonej w czasie ochrony prawnej, wyznaczonej przez ustawodawcę

${ }^{19}$ Wyrok SN z dnia 25 kwietnia 1973 r., I CR 91/73 (OSNCP 1974, nr 3, poz. 50).

${ }^{20}$ J. Barta, R. Markiewicz (red.), Ustawa..., (art. 8, uw. 5).

${ }^{21}$ M. Jankowska, Autor i prawo do autorstwa, Warszawa 2011, s. 328.

${ }^{22}$ Horacy, Exegi monumentum aere perennius, Pieśń III, 30.

${ }^{23}$ Więcej o polach eksploatacji art. 50 ustawy z dnia 4 lutego 1994 roku o prawie autorskim i prawach pokrewnych (Dz.U. z 2017 r., poz. 880).

24 Więcej na temat wynagrodzenia twórcy D. Sokołowska, Prawo twórcy do wynagrodzenia w prawie autorskim, Poznań 2013, s. 564. 
na 70 lat $^{25}$. W polskim systemie prawnym zapewniono możliwość zbycia praw majątkowych. Zasadą jest przenoszalność majątkowych praw autorskich inter vivos, jak i mortis causa $^{26}$.

Regulacje uprawnień twórcy ustawodawca zawarł nie tylko w prawie autorskim, czy prawie własności przemysłowej, ale również w prawie cywilnym. Już bowiem w art. 23 kodeksu cywilnego czytamy, że „twórczość naukowa, artystyczna, wynalazcza i racjonalizatorska, pozostają pod ochroną prawa cywilnego niezależnie od ochrony przewidzianej w innych przepisach”. Artykuł $24 \S 1$ i 2 kodeksu cywilnego zapewnia ochronę prawną dobrom osobistym i wskazuje na środki tej ochrony w postępowaniu przed sądem, zaś $\S 3$ wskazuje, że ochrona dóbr osobistych nie wpływa w żaden sposób na ochronę wynikającą z prawa autorskiego czy też prawa wynalazczego. Zarówno autorskie prawa osobiste jak i cywilne dobra osobiste mają charakter niemajątkowy, chociaż te pierwsze coraz częściej służą realizacji korzyści majątkowych związanych z twórczością ${ }^{27}$. W poglądach doktryny trudno doszukiwać się spójnego i jednolitego traktowania dóbr osobistych definiowanych w kodeksie cywilnym i autorskich dóbr osobistych. R. Markiewicz uważa, że osobiste dobra autorskie, określone w art. 16 prawa autorskiego należą do powszechnych dóbr osobi$\operatorname{stych}^{28}$, gdy tymczasem A. Wojciechowska uważa, że nie są one wartościami porównywalnymi z powszechnymi dobrami osobistymi w ujęciu cywilistycznym ${ }^{29}$. Judykatura przyjmuje, że osobiste dobra autorskie są szczególną kategorią powszechnych dóbr osobistych. W wyroku Sądu Najwyższego z dnia 7 listopada 2003 r., V CK 391/02 podkreślono, odwołując sie do analogicznych orzeczeń, że, ,że autorskie prawa osobiste chronione przez Prawo autorskie (art. 16 i 78 tego Prawa), podlegają także ochronie przewidzianej w art. 23 i 24 k.c. Środki ochrony określone przepisami prawa autorskiego i przepisami kodeksu cywilnego mogą być stosowane zarówno kumulatywnie, jak i alternatywnie, a decydujący w tej mierze powinien być wybór osoby zainteresowanej (wyroki Sądu Najwyższego z dnia 3 września 1998 r., I CKN 818/97, OSNC 1999, nr 1, poz. 21 i z dnia 5 stycznia 2001 r., V CKN 499/00, niepubl.)"30.

Niezależnie od środków ochrony prawnej, od źródeł tej ochrony, jednymi z najistotniejszych elementów gwarantujących twórcom komfort tworzenia są wolność i swoboda twórcza. Tylko bowiem w warunkach wolności i swobody twórczej możliwe jest kreowanie indywidualizmu twórcy, w tym twórcy dzieł naukowych. Próbę zdefiniowania, w oparciu o doktrynę i przepisy prawa, wolności nauki, dzieł naukowych podjęto poniżej.

25 Art. 36-39 ustawy z dnia 4 lutego 1994 roku o prawie autorskim i prawach pokrewnych.

26 Art. 41 ust. 1 pkt 1 ustawy z dnia 4 lutego 1994 roku o prawie autorskim i prawach pokrewnych.

${ }^{27}$ G. Tylec, Dobra osobiste a inne dobra prawne o charakterze osobistym chronione post mortem [w:] Non omnis moriar. Osobiste i majątkowe aspekty prawne śmierci człowieka. Zagadnienia wybrane, red. nauk. J. Gołaczyński, J. Mazurkiewicz, J. Turłukowski, D. Karkut, Wrocław 2015, s. 826.

${ }^{28}$ R. Markiewicz, Dzieto literackie i jego twórca w polskim prawie autorskim, Kraków 1984, s. 89-91.

29 A. Wojciechowska, Czy autorskie dobra osobiste sq dobrami osobistymi prawa cywilnego?, „Kwartalnik Prawa Prywatnego” 1994, nr 3, s. 371-391.

30 Wyrok SN z dnia 7 listopada 2003 r., V CK 391/02, OSNIC 2004/12/203. 


\section{PRAWNE I ETYCZNE ROZWAŻANIA NA TEMAT WOLNOŚCI NAUKI}

Twórcy, niezależnie od wieku, stanu umysłu, wykształcenia przysługuje konstytucyjne prawo statuujące wolność twórczą. Autor dzieła w demokratycznym systemie prawnym działa $w$ ramach wolności twórczej, co uwidacznia ustrojodawca następującym zapisem konstytucyjnym. „Każdemu zapewnia się wolność twórczości artystycznej, badań naukowych oraz ogłaszania ich wyników, wolność nauczania, a także wolność korzystania z dóbr kultury" ${ }^{31}$. Treść zapisu konstytucyjnego zrównuje w gwarantowaniu wolności twórczej autora dzieła artystycznego z twórcą badań naukowych, ogłaszanych z reguły w pracy naukowej. Takie usytuowanie dwóch jakże różnych na pierwszy rzut oka dyscyplin - sztuki i nauki jest zamierzone, wobec niezaprzeczalnego faktu wymogu istnienia przesłanki samodzielnej kreacji, projekcji wyobraźni, niepowtarzalności itd. ${ }^{32}$ Czym w rzeczywistości jest wolność nauki? Odpowiedź na to pytanie zostanie poprzedzona wyjaśnieniem pojęć funkcjonujących w tym obszarze, takich jak nauka, twórczość naukowa i utwór naukowy.

Twórczość naukowa i utwór naukowy to pojęcia, które nie doczekały się ustawowej, odrębnej definicji, natomiast w literaturze przedmiotu były poddawane analizie i interpretacji zarówno językowej, jak i merytorycznej. Nauka to słowo towarzyszące człowiekowi od czasu, kiedy zauważył w sobie chęć poznania, zdobywania informacji o otaczającym go świecie, rzeczywistości. Nie sposób w tym opracowaniu, nawet w części przybliżyć historycznego ujęcia tego wyrazu i wielokrotnych prób jego definiowania. Warto jednak zauważyć, że pojęcie to było przedmiotem studiów Arystotelesa, który dokonał wyjątkowego podziału nauk na:

(1) teoretyczne, których celem jest formułowanie wiedzy dla niej samej( metafizyka, matematyka, fizyka),

(2) praktyczne, w których wiedza wykorzystywana jest dla osiągnięcia doskonałości moralnej( etyka, polityka),

(3) pojetyczne, formułujące wiedzę w celach wytworzenia określonych przedmiotów ${ }^{33}$.

Arystoteles traktował naukę w sposób niezwykle rygorystyczny, wymagał bowiem aby jej twierdzenia były konieczne, pewne, prawdziwe, niezmienne, a ich przedmiot musiał być rzeczywisty i ogólny. Zdobywanie wiedzy dla niej samej decydowało o tym, że nauki teoretyczne Arystoteles cenił najwyżej, wyróżniając w szczególności metafizykę ${ }^{34}$.

Definiując współcześnie naukę, T. Rutowski stwierdził: „Nauka jest to niesprzeczny zbiór sądów zaspokajających ogólnoludzkie zainteresowania intelektualne (względnie praktyczne potrzeby życiowe), wyrażonych w języku możliwie jednoznacznym, a więc zasadniczo rozumianym jednakowo przez wszystkich i to sądów możliwie najmocniej uzasadnionych" 35 . Pojęcie „nauka” odnosimy do działalności umysłowej i umysłowo-fizycznej człowieka, u której podstaw leży poznanie, jako pierwotna aktywność psychiczna człowieka $^{36}$. Nauka jako zbiór sądów autora, sposób ich argumentowania nie może sprowadzać

\footnotetext{
31 Art. 73 Konstytucji RP.

32 Por. S. Jarosz-Żukowska, Ł. Żukowski, Wolność badań naukowych i nauczania [w:] Realizacja $i$ ochrona konstytucyjnych wolności i praw jednostki w polskim porządku prawnym, red. M. Jabłoński, Wrocław 2014, s. 715.

${ }^{33}$ E. König, Filozofia pierwsza Arystotelesa jako uniwersalna nauka o archaí, przekład M. Bogaczyk-Vormayr, Filo Sofija, nr 22 (2013/3), s. 295-311.

${ }^{34}$ T. Rutowski, Rozwój pojęcia nauki, „Studia Płockie” 1974, nr 2, s. 155-166.

35 Ibidem, s. 161-162.

${ }^{36}$ S. Kamiński, Nauka i metoda. Pojecie nauki i klasyfikacja nauk, Lublin 1992, s. 13.
} 
się li tylko do porządkowania posiadanej wiedzy - informacji, nie można bowiem sprowadzić uczonego do roli swoistego kustosza katalogującego, „odkurzającego” posiadane zasoby wiedzy ${ }^{37}$. Z kolei wolność badań naukowych bezsprzecznie kojarzy się ze swobodą wyboru - przedmiotu badań, metod i środków badawczych, sposobu prezentacji rezultatów bądź prawa do rezygnacji z upublicznienia rezultatów ${ }^{38}$. Usystematyzowana wiedza, poprzedzona badaniami naukowymi zostaje następnie upubliczniona jako informacja naukowa, która wykorzystywana jest między innymi w procesie nauczania. Trudno wyobrazić sobie demokratyczny porządek bez zapewnienia nauce wolności. Stąd też zainteresowanie tym pojęciem, łączącym w sobie wolność badań naukowych i wolność nauczania ${ }^{39}$ prawa międzynarodowego.

W art. 27 Powszechnej Deklaracji Praw Człowieka, przyjętej przez Zgromadzenie Ogólne ONZ w dniu 10 marca 1948 roku zapisano: „1. Każdy człowiek ma prawo do swobodnego uczestniczenia w życiu kulturalnym społeczeństwa, do korzystania ze sztuki, do uczestniczenia w postępie nauki i korzystania z jego dobrodziejstw. 2. Każdy człowiek ma prawo do ochrony moralnych i materialnych korzyści wynikających z jakiejkolwiek jego działalności naukowej, literackiej lub artystycznej”.

Gwarancje te rozbudowano w Międzynarodowym Pakcie Praw Gospodarczych, Społecznych i Kulturalnych z 19 grudnia 1966 roku $^{40}$, gdzie w art. 15 potwierdzono, że strony Paktu uznają m.in. prawo każdego do korzystania z osiągnięć postępu naukowego i jego zastosowań, prawo autorów do korzystania z ochrony interesów moralnych i materialnych działalności naukowej, artystycznej i literackiej. W ust. 3 tegoż artykułu strony Paktu zobowiązały sie do poszanowania swobody koniecznej do prowadzenia badań naukowych i działalności twórczej. Konieczność zapewnienia wolności badaniom naukowym i sztuce dostrzeżono również w Karcie Praw Podstawowych Unii Europejskiej ${ }^{41}$. Wolność głoszenia wyników badań naukowych, określana wolnością publikacji jest pochodną wolności badań naukowych i mieści się w pojęciu wolności nauki ${ }^{42}$.

Efektem twórczości naukowej jest utwór naukowy. Próżno szukać ustawowej definicji utworu naukowego, chociaż ustawa z 4 lutego 1994 roku o prawie autorskim i prawie pokrewnym wymienia utwór naukowy w art. 1 ust. 2, pkt 1, w art. 14 reguluje pierwszeństwo do jego publikacji, a w art. 29 dopuszcza cytowanie utworów w analizie naukowej. Nie zdefiniowano również utworu naukowego w aktach prawa wykonawczego mających charakter urzędowy, jedynie w Komunikacie Ministra Nauki i Szkolnictwa Wyższego z dnia 29 maja 2013 r. w sprawie kryteriów i trybu oceny czasopism naukowych, w przypisie do

\footnotetext{
37 J. Sobczak Wolność badań naukowych- standardy europejskie i rzeczywistość polska, „Nauka i Szkolnictwo Wyższe" 2/30/2007, s. 62.

${ }^{38}$ Ibidem, s. 63.

39 L. Garlicki, Konstytucja RP, Komentarz, t. II, Warszawa 2016, s. 5 (art. 73).

40 Przyjętym przez Radę Państwa PRL 3 marca 1977 roku (Dz.U. z 1977 r., nr 38, poz. 169).

${ }^{41}$ Artykuł 13 KPPUE Wolność sztuki i nauki Sztuka i badania naukowe sq wolne od ograniczeń. Wolność akademicka jest szanowana.

42 J. Symonides Wolność akademicka jako kategoria praw człowieka. O potrzebie przyjęcia instrumentu międzynarodowego [w:] Księga jubileuszowa Profesora Tadeusza Jasudowicza, red. J. Białocerkiewicz, M. Balcerzak, A. Czeczko-Durlak, Toruń 2004, s. 418, za S. Jarosz-Żukowską, Wolność akademicka w kontekście komercjalizacji wyników badań naukowych [w:] Aktualne wyzwania ochrony wolności i praw jednostki: prace uczniów i wspótpracowników dedykowane Profesorowi Bogusławowi Banaszakowi, red. M. Jabłoński, S. Jarosz- Żukowska, Wrocław 2014, s. 222.
} 
pkt 10 lit. e, zdefiniowano artykuł naukowy jako ,prezentujący wyniki oryginalnych badań o charakterze empirycznym, teoretycznym, technicznym lub analitycznym zawierający tytuł publikacji, nazwiska i imiona autorów wraz z ich afiliacją i przedstawiający obecny stan wiedzy, metodykę badań, przebieg procesu badawczego, jego wyniki oraz wnioski, z przy-

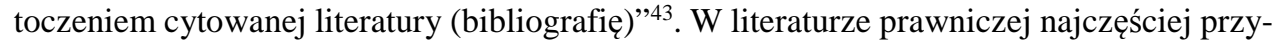
woływana jest definicja dzieła naukowego wprowadzona przez prof. H. Haberstumpfa, który wyróżnił dwie cechy w utworze naukowym, odróżniające go od pozostałych utworów, mianowicie informacyjny cel oraz zorientowanie na przedstawiony w nim obiektywnie istniejący stan rzeczy ${ }^{44}$. R. Markiewicz i J. Barta dodają do tej definicji jeszcze to, że naukowy charakter można przypisać utworom stanowiącym rezultat naukowego procesu poznawczego ${ }^{45}$.

Skoro prawo nie definiuje odrębnie dzieła naukowego, uznać należy, że regulacje, zawarte w prawie autorskim, odnoszące się ogólnie do „utworu”(art. 1 i inne) zachowują aktualność także wobec utworu naukowego. Twórczego charakteru dzieła naukowego należy dopatrywać się w ich subiektywnej nowości(oryginalności) i samodzielności ${ }^{46}$. Dzieło naukowe wyróżnia się zarysowaniem problemu i próbą jego wyjaśnienia, stawianą tezą i próbą jej udowodnienia bądź obalenia. W działach naukowych eksponowane są prawdy naukowe, sformułowane i wykryte przez autora w drodze spekulacji, doświadczenia, odniesienia do rzeczywistości ${ }^{47}$. Zdaniem R. Markiewicza to właściwy dobór argumentów i przykładów czynią utwór naukowym ${ }^{48}$.

Wolność i własność to pojęcia przejawiające się w tym artykule nader często, to słowa - symbole, stanowiące fundament demokratycznego porządku prawnego, ostoję liberalizmu, wreszcie to sztandarowe hasła myśli oświecenia. Wolność i własność prywatna zapewniają rozwój ekonomiczny, naukowy, kulturalny.

Czy w takiej sytuacji są to kategorie niczym nieskrępowane? Czy człowiek nauki jest w swojej wolności nieograniczony? Czy własność, w tym własność intelektualna jest prawem absolutnym? „Działalność naukowa może polegać na osiągnięciu nowszego i bardziej racjonalnego potwierdzenia wcześniejszych osiągnięć, może ona jednak wcześniej zbudowany gmach wiedzy ocenić jako fałszywy i tym samym obalić"49.

W tym znaczeniu wolność twórczości naukowej to nie tylko wykorzystanie istniejących zasobów intelektu, ale także stała weryfikacja prawd i twierdzeń, dotyczących świata,

\footnotetext{
${ }^{43}$ Zob. www.bip. nauka gov.pl/wykaz-czasopism-naukowych/komunikat-ministra-nauki-i-szkolnictwa-wyzszego-z-dnia-29-maja-2013-r-w-sprawie-kryteriow-i-trybu-oceny-czasopism-naukowych/ (dostęp: 10 stycznia 2018 r.).

${ }^{44}$ H. Haberstumpf, Zur Individualität wissenschaftlicher Sprachwerke, Freiburg 1982, s. 22-26; R. Markiewicz Obrona prac naukowych. Autorskoprawna ochrona prac naukowych, , [w:] ZNUJ 1990/4, s.19.

45 J. Barta, R. Markiewicz Prawo autorskie i prawa pokrewne, Warszawa 2011, s. 156; D. Sokołowska, Pojęcie i postacie utworu naukowego w świetle prawa autorskiego, [w:] Ruch Prawniczy, Ekonomiczny i Socjologiczny 2015/2, s. 82.

46 A. Szewc, Dzieła naukowe i ich status w prawie autorskim, „Państwo i Prawo” 1997/10, s. 25.

${ }^{47}$ Ibidem, s. 24.

48 R. Markiewicz, Obrona..., s. 20.

${ }^{49}$ Ch. Starck, Wolność badań naukowych i jej granice, „Przegląd Sejmowy” nr 3(80)2007, s. 46.
} 
technologii i człowieka ${ }^{50}$. Nauka jest niewątpliwie efektem działalności twórczej człowieka, której celem jest poszerzanie aktualnej wiedzy w warunkach szeroko rozumianej wolności.

Nie wymaga dowodzenia teza wypowiadana zarówno przez św. Augustyna, FrançoisMarie Arouet (Woltera) - moja wolność kończy się tam, gdzie zaczyna się wolność drugiego człowieka.

W art. 4 Deklaracji Praw Człowieka i Obywatela z 26 sierpnia 1789 roku czytamy: „Wolność polega na czynieniu tego wszystkiego, co nie szkodzi drugiemu. W ten sposób nie ma innych granic dla używania praw naturalnych człowieka jak te, które zapewniają używanie tychże praw innym członkom społeczeństwa. Te granice może określić tylko ustawa”. Konstytucyjna gwarancja nienaruszalności godności człowieka określona w art. 30, ochrona prawna wolności człowieka - art. 31 ust. 1 oraz konstytucyjny nakaz poszanowania wolności i praw innych osób z art. 31 ust. 2 urzeczywistniają prawdę głoszoną przez św. Augustyna czy Woltera, potwierdzoną zacytowaną Deklaracją. Wprowadzenie zasady proporcjonalności w art. 31 ust. 3 Konstytucji, zapewniło z kolei możliwość ograniczenia wolności i praw tylko w drodze ustawy i tylko wówczas, gdy wymaga tego bezpieczeństwo lub porządek publiczny, ochrona środowiska, zdrowia i moralności publicznej, albo wolność i prawa innych osób. Wolność nauki, jako wolność twórcza, przejawiająca się w swobodzie wyboru tematu, środków wyrazu, czy metod badawczych nie może naruszać wolności i praw innego człowieka.

Prawne ograniczenia wolności nauki wyprowadzić można wprost z Konstytucji, która gwarantuje nienaruszalność godności jako prawa przyrodzonego, zapewnia ochronę życia, nietykalności cielesnej, wolności osobistej, wreszcie tworzy zakaz przeprowadzania eksperymentów medycznych bez zgody człowieka.

Swoboda wyrazu twórczego nie może pozostawać w kolizji z innymi dobrami pozostającymi pod ochroną cywilnoprawną. Wreszcie wolność twórcza nie może naruszać cudzej własności, czy innych praw majątkowych.

Twórca, w szczególności ten, który funkcjonuje w obszarach nauki zobligowany jest prawnie i moralnie do szczególnej rzetelności i uczciwości. Skoro nauka jest jednym z najistotniejszych elementów kultury umysłowej człowieka, skoro kształtuje rzeczywistość i wpływa na całokształt życia ludzkiego w wymiarze jednostkowym i społecznym ${ }^{51}$ wymagania i standardy wobec niej stawiane powinny być ponadprzeciętne.

Rygorystyczne ujęcie plagiatu w systemie prawa jest zrozumiałe, jeżeli zważy się na bezprawność w działaniu twórcy, który zawłaszcza cudzą własność intelektualną, dysponując nią jak swoją. Naganność takiego zachowania dostrzegali już starożytni twórcy, wprowadzając do języka słowo plagium, plagiarus oznaczające bezprawne zniewolenie człowieka wyzwolonego i handlarza niewolnikami. Tak właśnie rzymski poeta Marcjalis ${ }^{52}$ określił swojego kolegę ,,po fachu” Fidentina, kiedy ten recytował publicznie jego wiersze,

\footnotetext{
${ }^{50}$ M. Jabłoński, J. Węgrzyn, Wolność twórczości artystycznej i naukowej oraz dostępu do dóbr kultury [w:] Realizacja i ochrona konstytucyjnych wolności i praw jednostki w polskim porzadku prawnym, red. M. Jabłoński, Wrocław 2014, s. 692.

51 St. Kowalczyk, Etyka - zagrożenie wolności nauki? [w:] Annales. Etyka w życiu gospodarczym, Lublin 2010, s. 19.

52 Więcej o Marcjalisie: https://www.imperiumromanum.edu.pl, Biografie Rzymian, Marcjaliis Marcus Valerius Martialis), rzymski poeta (ok. 40-102 n.e.).
} 
przypisując sobie ich autorstwo. W znaczeniu współczesnym plagiat, z łac. plagiatus oznacza kradzież.

Obraz, grafika, fotografia, odkrycia, piosenki, wiersz, wynalazek, praca dyplomowa, doktorska, publikacja naukowa mogą stać się przedmiotem bezprawnego przywłaszczenia autorstwa.

W polskim prawie chroniącym własność intelektualną zachowanie polegające na przywłaszczeniu sobie autorstwa lub wprowadzenia w błąd co do autorstwa jest przestępstwem ściganym z oskarżenia publicznego ${ }^{53}$.

Bezprawność działania, krzywda wyrządzona twórcy, wprowadzenie w błąd osób trzecich co do autorstwa dzieła czynią plagiat najcięższym przewinieniem również w środowisku akademickim. Nie istnieją w tym przypadku okoliczności łagodzące, nie można powołać się na nieświadomość prawną, bowiem plagiat jako przestępstwo jest działaniem umyślnym, podobnie jak kradzież stypizowana w art. 278 kodeksu karnego. Wprawdzie ustawodawca określił czynność sprawczą, w jej podstawowej formie jako przywłaszczenie, to nie można jej utożsamiać z przywłaszczeniem mienia z art. 284 k.k. Tam bowiem „,rzecz przywłaszczana znajduje się we władaniu sprawcy, a przywłaszczane prawo może on wykonywać” 54 . W przypadku plagiatu, w powszechnym odbiorze mamy do czynienia $\mathrm{z}$,kradzieżą intelektualną".

Plagiat narusza osobiste prawa autorskie twórcy, ale tworzy też zagrożenie dla jego interesów majątkowych, stąd też w przepisach ustawy, w art. 78 przewidziano roszczenia o charakterze cywilnoprawnym, które mogą funkcjonować w zbiegu z roszczeniami określonymi w art. $24 \S 3$ kodeksu cywilnego.

Nauczyciele akademiccy dodatkowo poniosą odpowiedzialność dyscyplinarną, o której mowa w art. 139 prawa o szkolnictwie wyższym ${ }^{55}$. W ustawie z dnia 14 marca $2003 \mathrm{r}$. o stopniach naukowych i tytule naukowym oraz o stopniach i tytule w zakresie sztuk, w art. 29a przewidziano stwierdzenie nieważności postępowania w sprawie nadania tytułu naukowego lub stopnia, w przypadku ujawnienia przypisania sobie cudzego autorstwa ${ }^{56}$. Poza wymiarem prawno-karnym i cywilno-prawnym plagiatu, środowiska naukowe zakwalifikowały działania związane $\mathrm{z}$ wykorzystaniem cudzego autorstwa jako rażące uchybienie moralności. Niesamodzielność twórcza uznana została za działanie podważające sens nauki przez społeczność akademicką Uniwersytetu Jagiellońskiego. „Jakiekolwiek uchybienie zasadzie samodzielności stanowi pogwałcenie fundamentalnych reguł i idei posłannictwa nauki, musi tedy być uznane za szczególnie godną potępienia postawę etyczną członka społeczności akademickiej, zarazem też stanowiąc ciężkie naruszenie prawa”, w tak ostrych słowach Akademicki Kodeks Wartości Uniwersytetu Jagiellońskiego odniósł się do jawnych plagiatów, kryptoplagiatów, przypadków dopisywania się do cudzych prac czy zawyżania faktycznego udziału twórczego, a także autoplagiatów w znaczeniu wielokrotnego sprzedawania swoich produktów ${ }^{57}$. Za niemoralny uznano proceder ,handlowania” pracami

53 Art. 115 Prawa autorskiego i art. 303 Prawa własności przemysłowej (tj. Dz.U. z 2017 r., poz. 776).

${ }^{54}$ M. Mozgawa (red.), Kodeks karny. Komentarz aktualizowany, e- LEX 2017, art. 284.

${ }^{55}$ Ustawa z dnia 27 lipca 2005 r. - Prawo o szkolnictwie wyższym (tekst jedn. Dz.U. z 2017 r., poz. 2183).

${ }^{56}$ Ustawa z dnia 14 marca 2003 r. o stopniach naukowych i tytule naukowym oraz o stopniach i tytule w zakresie sztuk (tekst jedn. Dz.U. z 2017 r., poz. 1789).

${ }^{57}$ Akademicki Kodeks Wartości przyjęty na posiedzeniu Senatu Uniwersytetu Jagiellońskiego w dniu 25 czerwca 2003 r., s. 4. 
dyplomowymi czy też opracowaniami, dostrzegając odpowiedzialność zarówno autorów faktycznych jak i rzekomych ${ }^{58}$. Plagiat potraktowany został jako przejaw szczególnej ignorancji i nierzetelności w nauce przez Polską Akademię Nauk uznającą plagiaryzm za rażące przewinienie, obok fabrykowania i fałszowania wyników badań naukowych ${ }^{59}$. Popełnianiem plagiatów nazwano we wspomnianym dokumencie, przywłaszczenie cudzych idei, wyników badań lub słów, bez poprawnego podania źródła, naruszających prawa własności intelektualnej ${ }^{60}$. W grupie rażących przewinień nie znalazł się natomiast autoplagiat. Natomiast w dziale poświęconym ,praktykom autorskim i wydawniczym” podkreślono, że ponowne publikowanie tej samej pracy wymaga zgody redaktorów, przy czym zawsze należy uczynić odwołanie do pierwszej publikacji. Dodatkowy wymóg postawiono wpisywaniu ponownej publikacji do dorobku naukowego, w którym opracowania powiązane ze sobą treściowo w istotnych częściach i zakresie należy wykazać jako jedną pozycję ${ }^{61}$.

Dezaprobata dla zjawiska plagiatu nie jest jedynie domeną polskiego prawa. Przywłaszczenie autorstwa cudzego dzieła zostało wyeksponowane jako jedno z najcięższych przewinień przez dokument federalny USA - Polityka Federalna w zakresie Wykroczeń w Pracach Badawczych, opracowany przez Urząd d/s Polityki w Dziedzinie Nauki i Technologii $^{62}$. Poza przypisaniem sobie autorstwa idei, metod, wyników badan, określeń - bez właściwego odniesienia, do definicji plagiatu dołączono również nieautoryzowane wykorzystanie informacji uzyskane w trakcie poufnego recenzowania cudzej pracy. W Europejskim Kodeksie Naukowca, akcie prawnym skierowanym do wszystkich przedstawicieli nauki Unii Europejskiej sformułowano przekaz, w rozdziale poświęconym odpowiedzialności zawodowej o treści „Naukowcy nie mogą dopuścić się plagiatu w jakiejkolwiek formie i muszą przestrzegać zasady poszanowania praw własności intelektualnej oraz wspólnej własności danych w przypadku badań prowadzonych we współpracy z opiekunem/opiekunami i/lub innymi naukowcami"63.

Zrozumiałe jest piętnowanie zjawiska plagiatu, traktowanego w społecznym odbiorze na równi z kradzieżą, który stanowi naruszenie prawa własności i w żaden sposób nie może być kojarzony z wolnością i swobodą twórczą. Zakres odpowiedzialności osoby bezprawnie wykorzystującej cudzą twórczość, w znaczeniu przywłaszczenia autorstwa jest niezwykle rozbudowany, począwszy od odpowiedzialności deliktowej, przez karną po zawodową.

Zastanawiające i nie zawsze jednoznaczne jest wprowadzenie do dziedziny prawa autorskiego zjawiska autoplagiatu i czynienie rozważań właśnie na tym gruncie. Czym jest autoplagiat, czy jest działaniem bezprawnym czy tylko nieetycznym? Czy jest sztucznie wykreowanym pojęciem, będącym znakiem czasu, czy rzeczywistym problemem, szczególnie w środowisku akademickim?

\footnotetext{
58 Ibidem, s. 4.

${ }^{59}$ Załącznik do uchwały nr 3/2016 Zgromadzenia Ogólnego PAN z dnia 1 grudnia 2016 roku, Kodeks etyki pracownika naukowego, s. 10.

${ }^{60}$ Ibidem, s. 10.

61 Ibidem, s. 7.

${ }^{62} \mathrm{https}$ ://ori.hhs.gov/chapter-2-research-misconduct-office-science-and-technology-policy (dostęp: 12 stycznia 2018 r.).

${ }^{63} \mathrm{http} / / /$ www.nauka.gov.pl/europejska-karta-naukowca (dostęp: 12 stycznia 2018 r.).
} 


\section{ZARZUT AUTOPLAGIATU OGRANICZENIEM WŁASNOŚCI I WOLNOŚCI TWÓRCZEJ?}

Podobnie jak plagiat nie jest terminem prawnym, nie został zdefiniowany ani w prawie własności intelektualnej (prawo autorskie, prawo własności przemysłowej) ani też w pozakodeksowych przepisach karnych, tak samo autoplagiat nie jest pojęciem normatywnym. Niemniej jednak uznane i historycznie udokumentowane pojęcie plagiatu pozwoliło na jednoznacznie rozumienie go jako bezprawnego przywłaszczenia (kradzieży) wytworu cudzego intelektu.

Tymczasem, jak wielokrotnie powtarzano w literaturze przedmiotu, słowo autoplagiat zawiera w sobie immamentną sprzeczność, bowiem nie można okraść samego siebie, nie można dokonać zaboru własnego mienia czy też autorstwa swojego utworu ${ }^{64}$. Co więc oznacza pojęcie, które w przytoczonym powyżej Akademickim Kodeksie Wartości Uniwersytetu Jagiellońskiego zrównano z plagiatem i kryptoplagiatem i ich pejoratywnym oddziaływaniu na naukę. Tam nadano autoplagiatowi znaczenie wielokrotnego sprzedawania swoich produktów. Przenosząc to określenie na grunt autorskich praw majątkowych, to do twórcy należy decyzja kiedy, w jakim zakresie i na jakich warunkach przeniesie majątkowe prawa do utworu na inny podmiot. Umowa, którą podpisze w tym zakresie, dookreślająca warunki zbycia majątkowych praw autorskich będzie wiążąca dla twórcy. Swoboda zawierania umów, o której mowa w art. $353^{1}$ kodeksu cywilnego, doznająca pewnych ograniczeń na gruncie prawa autorskiego, będzie miała zdecydowany wpływ na kształtowanie zapisów umowy przenoszącej majątkowe prawa autorskie czy umowy licencyjnej. Zmiana podmiotu uprawnionego do dysponowania prawami majątkowymi jest równoznaczna dla twórcy z zakazem rozporządzania majątkowymi prawami do utworu - chyba że umowa stanowi inaczej.

Zachowanie twórcy, który po zbyciu majątkowych uprawnień dokona ponownego rozporządzenia nimi będzie traktowane jako naruszenie prawa. Nemo plus iuris in alium transferre potest quam ipse habet, twórca nie może zadysponować prawem, którego nie posiada. Uznanie tego zachowania za naruszenie prawa autorskiego budzi jednak moje wątpliwości. Konsekwencji prawnych takiego działania należało by szukać raczej na gruncie prawa karnego i cywilnego. Czym innym, jak nie oszustwem stypizowanym w art. $286 \S 1$ kodeksu karnego, będzie zawarcie kolejnej umowy o przeniesieniu majątkowych praw autorskich na kolejny podmiot, w sytuacji, gdy autor utracił tytuł prawny do takiego działania? Ocena prawno-karna prowadzi do wniosku, że autor wprowadza w błąd (wydawnictwo, producenta) co do tak istotnej okoliczności jaką jest prawo do utworu i doprowadza w efekcie do niekorzystnego rozporządzenia mieniem (nakłady marketingowe, wydawnicze, wynagrodzenie twórcy). Fakt, przestępstwo oszustwa jest działaniem kierunkowym, sprawca działa w celu osiągnięcia korzyści majątkowej - taką będzie wynagrodzenie autorskie, sprawca działa z zamiarem bezpośrednim - tak należy rozumieć sprzedaż dobra, do którego utracono tytuł prawny i wreszcie czynność sprawcza polega na wprowadzeniu w błąd, przez które należy rozumieć zapewnienie o władztwie nad prawami majątkowymi do utworu. Opisany występek może przybierać różne formy stadialne od usiłowania po dokonanie.

\footnotetext{
${ }^{64}$ Zob. S. Stanisławska-Kloc, Plagiat contra autoplagiat [w] Spory o wtasność intelektualna: Księga jubileuszowa dedykowana profesorom Januszowi Barcie i Ryszardowi Markiewiczowi, red. A. Matlak, S. Stanisławska-Kloc, Warszawa 2013.
} 
Pokrzywdzenie nabywcy może skutkować odpowiedzialnością z tytułu nienależytego wykonania zobowiązania, czy też z tytułu rękojmi za wady prawne ${ }^{65}$.

A co w sytuacji kiedy twórca nie jest związany umową przenoszącą majątkowe prawa autorskie, lub umową o licencję wyłączną, czy dysponuje pełnią władztwa do swojego dzieła, czy może czynić ze swojego prawa własności nieograniczony użytek, wielokrotnie je publikując? W środowisku naukowym panuje pogląd, że wykorzystywanie wcześniejszych dzieł w utworach nowotworzonych, przy jednoczesnej zmianie tytułu, czy „kosmetycznych" modyfikacjach treści, bez wyraźnego odwołania się do autorstwa służy stworzeniu mylnego wyobrażenia, że powstaje dzieło nacechowane oryginalnością, nowością. Powodów takiego stanu rzeczy upatrywać należy w braku pomysłowości, talentu, zaangażowania, czy bardzo częstego „zmęczenia twórczego”.

Celem twórcy jest mnożenie publikacji naukowych, zwiększenie dorobku naukowego, stanowiącego kryterium awansu ${ }^{66}$. W przepisach prawa własności intelektualnej nie zakazano wielokrotnego wykorzystywania swojej twórczości. Nie wprowadzono reguł optymalnej „,budowy” utworu. Skoro więc nie uznano za bezprawne działania twórcy posługującego się swoją wcześniej wytworzoną myślą, nie skonstruowano przepisu karnego polegającego na wprowadzeniu w błąd co do nowości, czy też oryginalności utworu, to skąd piętnowanie takich zachowań i formułowania zarzutów o naruszenie zasad etyki, implikujących konsekwencje dyscyplinarne i zawodowe. Punktem wyjścia powinno być przywołanie nieodłącznych cech utworu, w rozumieniu prawa autorskiego. Jedynie twórcze i indywidualne przejawy działalności naszego umysłu będą zasługiwały na miano utworu. Analogiczne wymagania stawiane są utworom naukowym, przy czym ich przesłanie i oddziaływanie na rzeczywistość z jednej strony czynią tą kategorię utworów wyjątkową z drugiej zaś wiąże się $\mathrm{z}$ nią większa odpowiedzialność. Skopiowanie treści własnego utworu do nowopowstałego dzieła nie może być traktowane jako działanie twórcze, nawet kiedy autor wprowadzi nieznaczne zmiany, kiedy inaczej go zatytułuje. Nie ma bowiem w takim działaniu kreatywności, nie dopatrzymy się w nim tzw. nowości subiektywnej, a twór, który powstanie dzięki zabiegom technicznym, redakcyjnym, będzie miał na celu wywołanie wyobrażenia u odbiorców, że mają do czynienia z oryginalnością i niepowtarzalnością autora. Pozbawienie utworu jego ustawowych cech, uczyni go bezwartościowym. I choć swoboda tworzenia jest wartością gwarantowaną przez Konstytucję, to nie może być traktowana jako ius absolu$t_{u m}{ }^{67}$. Nie jest prawem absolutnym, jako prawo o wymiarze konstytucyjnym może być ograniczone jedynie w drodze ustawy. Tym ograniczeniem ustawowym, będzie legalna definicja utworu sformułowana $\mathrm{w}$ art. 1 prawa autorskiego. W doktrynie przyjmuje się, że twórca ma prawo odwołać się do wyników swojej wcześniejszej intelektualnej działalności, z wyraźnym wskazaniem źródła pochodzenia przywołanego tekstu ${ }^{68}$. Nie ma zakreślonych granic ani jakościowych ani też ilościowych takich odwołań. Wydaje się logicznym, że taką granicę będzie wyznaczała definicja utworu. Niekończące się cytowanie cudzej twórczości, przywoływanie własnej z prawidłowym, z punktu widzenia formalnego wskazaniem źródła mogą w równym stopniu co autoplagiat pozbawić utwór cech oryginalności. Nie sposób

65 J. Barta, R. Markiewicz, Prawo autorskie. Komentarz, Warszawa 2011, s. 388.

${ }^{66}$ S. Stanisławska-Kloc, Plagiat i autoplagiat, Biuro Analiz Sejmowych, nr 16 (108)2011, s. 4.

${ }^{67}$ Zob. J. Sieńczyło-Chlabicz, J. Banasiuk, Pojęcie $i$ istota autoplagiatu w twórczości naukowej, „Państwo i Prawo” 2012, nr 3, s. 8.

68 Ibidem, s. 13. 
oprzeć się wrażeniu, że cele cytatu, wyznaczone przez ustawodawcę w art. 29 prawa autorskiego, często są pomijane, a przywoływane fragmenty cudzej kreacji wypełniają treść nowo powstałego utworu ${ }^{69}$.

Współczesna nauka, szczególnie w dziedzinie nauk humanistycznych i społecznych nie wymaga kreacji ex nihilo. Tempo jej rozwoju, stopień zaawansowania a zarazem zróżnicowania decydują o tym, że teorie i poglądy poprzedników stają się pożywką do nowych kreacji intelektualnych, często polemicznych, ale zarazem nowatorskich. Nowe spojrzenie na problem naukowy, wielokrotnie omawiany, uzupełnienie i kontynuacja myśli twórczej czynią dzieło oryginalnym. Teoretycznie nic nie stoi na przeszkodzie, abyśmy odwołując się w nowotworzonym utworze do własnych, wcześniejszych dzieł, dokonali swoistej autokrytyki, popartej nowymi przemyśleniami, wynikającymi z rozwoju nauki. Tak więc, czy autoplagiat stał się rzeczywistym czy sztucznie wykreowanym problemem środowiska akademickiego? Czy takim samym problemem nie stało się mnożenie utworów opartych w przeważającej większości o cytat i swoisty autocytat? Poddając analizie prawno-karnej zachowania polegające na autoplagiatowaniu, czy też powielaniu w formie niekończących się cytatów cudzej lub własnej twórczości zwrócić należy uwagę na zbliżony cel, jakim jest zwiększenie swojego dorobku naukowego i przekonanie odbiorców o oryginalności, rozumianej jako indywidualność tych dzieł. Nie można wykluczyć, że w konkretnych zachowaniach należałoby dopatrzyć się występku, o którym mowa w art. 272 k.k. ${ }^{70}$, wyłudzenia poświadczenia nieprawdy poprzez uzyskanie tytułu naukowego, którego warunkiem było zgromadzenie dorobku naukowego autora, jego oryginalnej i nowatorskiej myśli.

Poszukując przyczyn takiego stanu rzeczy należy stwierdzić, że nie są one jednolite. Tworzenie kreacji intelektualnych, które w rzeczywistości nie zawierają ustawowych znamion utworu, bowiem opierają się na autoplagiacie, autopowtórzeniach bądź też niezliczonej liczbie cytatów, jest wynikiem z jednej strony braku pomysłowości, nowatorskich koncepcji, z drugiej zaś przemożnej chęci sprostania prawnym wymaganiom uzyskania awansu naukowego. System punktowy oceny dorobku naukowego, jako kryterium awansu determinuje sytuacje, w których to ilość a nie, jakość publikowanych dzieł będzie decydująca.

\section{PODSUMOWANIE}

Kończąc powyższe rozważania, przyjąć należy, że formułowanie zarzutu autoplagiatu nie stanowi ograniczenia władztwa twórcy do utworu, nie jest też wymierzone w jego poczucie wolności i swobody twórczej. Jakkolwiek autoplagiat nie jest ,zabiegiem” bezprawnym, to w ocenie przedstawicieli nauki, literatury, a i sztuki jest wyjątkowo krytycznie oceniany. Skoro jednak zarówno wolność nauki jak i swoboda w doborze środków i metod wyrazu nie mogą „,burzyć” legalnego pojęcia utworu, to równie krytycznie należy oceniać

\footnotetext{
${ }^{69}$ Art. 29 ustawy z dnia 4 lutego 1994 r. o prawie autorskim i prawach pokrewnych (tekst jedn. Dz.U. z 2017 r., poz. 880).

„Wolno przytaczać w utworach stanowiących samoistną całość urywki rozpowszechnionych utworów oraz rozpowszechnione utwory plastyczne, utwory fotograficzne lub drobne utwory w całości, w zakresie uzasadnionym celami cytatu, takimi jak wyjaśnianie, polemika, analiza krytyczna lub naukowa, nauczanie lub prawami gatunku twórczości”.

${ }^{70}$ Art. 272 k.k. „,Kto wyłudza poświadczenie nieprawdy przez podstępne wprowadzenie w błąd funkcjonariusza publicznego lub innej osoby upoważnionej do wystawienia dokumentu, podlega karze pozbawienia wolności do lat 3".
} 
inne działania ,redakcyjne”(wymienione powyżej) twórców naukowych, prowadzące do utraty oryginalności - subiektywnej nowości. Proces twórczy nie może bowiem sprowadzać się do poprawnego pod względem prawnym (ze wskazaniem źródła) przywoływania cudzych czy też własnych dzieł, bez wyraźniej myśli przewodniej autora, bez wskazania celu jaki zamierza osiągnąć i wreszcie bez końcowych wniosków. Nic nie stoi na przeszkodzie, aby autor dzieła naukowego podobnie - jak twórcy sztuki, próbował szokować swoimi przemyśleniami, prowokować i zmuszać odbiorców do innego spojrzenia na określony temat. Nie można bowiem oprzeć się wrażeniu, szczególnie w odniesieniu do publikacji prawniczych, że oto powstają kolejne „kopie” tego co już zostało powiedziane, przy użyciu tych samych, powtarzających się argumentów.

Wszak granice wolności i swobody twórczej wyznaczają nam nie tylko prawa innych osób, ale też cechy, bez których wytwory naszego umysłu nie byłyby utworami. Bo nie będzie odkryciem stwierdzenie, że tylko niepowtarzalność i oryginalność dzieła uczynią je niezapomnianym.

\section{LITERATURA}

1. Akademicki Kodeks Wartości Uniwersytetu Jagiellońskiego, przyjęty uchwałą Senatu UJ z 25 czerwca 2003 roku.

2. Barta J., Markiewicz R. (red.), Ustawa o prawie autorskim i prawach pokrewnych, Komentarz, wyd. V, e-LEX 2011.

3. Barta J., Markiewicz R., Prawo autorskie i prawa pokrewne, Warszawa 2011.

4. Barta J., Markiewicz R., Prawo autorskie. Komentarz, Warszawa 2011.

5. Dybowski T., Ochrona prawa wtasności na tle konstytucyjnej koncepcji źródet prawa w orzecznictwie TK [w:] Trybunat Konstytucyjny, Księga XV-lecia, red. F. Rymarz, A. Jankiewicz, Warszawa 2001.

6. Flisak D. (red.), Prawo autorskie i prawa pokrewne. Komentarz, e-LEX 2015.

7. Garlicki L., Konstytucja RP, Komentarz, t. II, Warszawa 2016.

8. Haberstumpf H., Zur Individualität wissenschaftlicher Sprachwerke, Freiburg 1982.

9. Horacy, Exegi monumentum aere perennius, Pieśń III.

10. Jabłoński M., Węgrzyn J., Wolność twórczości artystycznej i naukowej oraz dostępu do dóbr kultury [w:] Realizacja i ochrona konstytucyjnych wolności i praw jednostki w polskim porzadku prawnym, red. M. Jabłoński, Wrocław 2014.

11. Jankowska M., Autor i prawo do autorstwa, Warszawa 2011.

12. Jarosz-Żukowska S., Wolność akademicka w kontekście komercjalizacji wyników badań naukowych [w:] Aktualne wyzwania ochrony wolności i praw jednostki: prace uczniów i wspótpracowników dedykowane Profesorowi Bogusławowi Banaszakowi, red. M. Jabłoński, S. Jarosz-Żukowska, Wrocław 2014.

13. Jarosz-Żukowska S., Żukowski Ł., Wolność badań naukowych i nauczania [w:] Realizacja $i$ ochrona konstytucyjnych wolności i praw jednostki w polskim porzadku prawnym, red. M. Jabłoński, Wrocław 2014.

14. Kamiński S., Nauka i metoda. Pojęcie nauki i klasyfikacja nauk, Lublin 1992.

15. König E., Filozofia pierwsza Arystotelesa jako uniwersalna nauka o archaí, przekład M. Bogaczyk-Vormayr, [w:] Filo Sofija, nr 22 (2013/3).

16. Konstytucja Rzeczypospolitej Polskiej. Komentarz, pod red. L. Garlickiego, t. III, Warszawa 2003. 
17. Kodeks etyki pracownika naukowego, przyjęty uchwałą Zgromadzenia Ogólnego PAN nr 3/2016.

18. Kowalczyk S., Etyka - zagrożenie wolności nauki? [w:] Annales. Etyka w życiu gospodarczym, Lublin 2010.

19. Markiewicz R., Dzieło literackie i jego twórca w polskim prawie autorskim, Kraków 1984.

20. Markiewicz R., Obrona prac naukowych. Autorskoprawna ochrona prac naukowych, ZNUJ 1990/4.

21. Markiewicz R., Opinia prawna. dot. pojęcia utworu oraz pojęcia dokumentu urzędowego materiatu urzędowego w rozumieniu polskiego prawa autorskiego, http://www.informacjapubliczna.org.pl.

22. Mozgawa M. (red.), Kodeks karny. Komentarz aktualizowany e- LEX 2017.

23. Rutowski T., Rozwój pojęcia nauki w twórczości naukowej „Państwo i Prawo” 2012, nr 3.

24. Sarbiński R.M., Siciarek M. (red.), Prawo autorskie. Komentarz do wybranych przepisów, e-LEX 2017.

25. Schiller F., Listy o estetycznym wychowaniu człowieka, Pisma teoretyczne, wyd. Aletheia, Warszawa 2011.

26. Sieńczyło-Chlabicz J., Banasiuk J., Pojęcie i istota autoplagiatu w twórczości naukowej, „Państwo i Prawo” 2012, nr 3.

27. Sobczak J., Wolność badań naukowych - standardy europejskie i rzeczywistość polska, „Nauka i Szkolnictwo Wyższe” 2/30/2007.

28. Sokołowska D., Pojęcie i postacie utworu naukowego w świetle prawa autorskiego, „Ruch Prawniczy, Ekonomiczny i Socjologiczny” 2015/2.

29. Sokołowska D., Prawo twórcy do wynagrodzenia w prawie autorskim, Poznań 2013.

30. Stanisławska-Kloc S., Plagiat contra autoplagiat [w] Spory o wtasność intelektualna: Ksiegga jubileuszowa dedykowana profesorom Januszowi Barcie i Ryszardowi Markiewiczowi, red. A. Matlak, S. Stanisławska-Kloc, Warszawa 2013.

31. Stanisławska-Kloc S., Plagiat i autoplagiat, Biuro Analiz Sejmowych, nr 16 (108)2011.

32. Starck Ch., Wolność badań naukowych i jej granice, Przegląd Sejmowy 2007, nr 3(80).

33. Szewc A., Dzieła naukowe i ich status w prawie autorskim, „Państwo i Prawo” 1997/10.

34. Tylec G., Dobra osobiste a inne dobra prawne o charakterze osobistym chronione post mortem [w:] Non omnis moriar. Osobiste i majątkowe aspekty prawne śmierci człowieka. Zagadnienia wybrane, red. J. Gołaczyński, J. Mazurkiewicz, J. Turłukowski, D. Karkut,Wrocław 2015.

35. Wojciechowska A., Czy autorskie dobra osobiste sa dobrami osobistymi prawa cywilnego?, „Kwartalnik Prawa Prywatnego” 1994, nr 3.

\section{PRAWODAWSTWO}

1. Konstytucja RP z 2 kwietnia 1997 roku (Dz.U. z 1997 r., nr 78, poz. 483).

2. Ustawa z dnia 4 lutego 1994 r. o prawie autorskim i prawach pokrewnych (tekst jedn. Dz.U. z 2017 r., poz. 880).

3. Ustawa z dnia 30 czerwca 2000 r. - Prawo własności przemysłowej (tekst jedn. Dz.U. z 2017 r., poz. 776).

4. Ustawa z dnia 14 marca 2003 r. o stopniach naukowych i tytule naukowym oraz o stopniach i tytule w zakresie sztuki (tekst jedn. Dz.U. z 2017 r., poz. 1789). 
5. Ustawa z dnia 27 lipca 2005 r. - Prawo o szkolnictwie wyższym (tekst jedn. Dz.U. z 2017 r., poz. 2183).

6. Międzynarodowy Pakt Praw Gospodarczych, Społecznych i Kulturalnych z 19 grudnia 1966 r. (Dz.U. z 1977 r., nr 38, poz. 169).

7. Konwencja o Ustanowieniu Światowej Organizacji Własności Intelektualnej (Dz.U. nr 9 z 1975 r., poz. 49).

\title{
ORZECZNICTWO
}

1. Wyrok TK z dnia 22 czerwca 2015 roku, sygn. SK32/14, OTK-A 2015/6, poz. 84.

2. Wyrok SN z dnia 25 kwietnia 1973 r., I CR 91/73 (OSNCP 1974, nr 3, poz. 50).

3. Wyrok SN z dnia 7 listopada 2003 r., V CK 391/02 (OSNIC 2004/12/203).

4. Wyrok SN z dnia 25 stycznia 2006 r., I CK 281/05 (OSNC 2006, nr 11, poz. 286).

5. Wyrok SN z dnia 22 czerwca 2010 r., IV CSK 359/09 (OSP 2011, z. 5, poz. 59).

6. Wyrok NSA z dnia 12 marca 2010 r., II FSK 1791/08 (LEX nr 595971).

\section{NETOGRAFIA}

1. www. bip. nauka gov.pl/wykaz-czasopism-naukowych/komunikat-ministra-nauki-i-szkolnictwa-wyzszego-z-dnia-29-maja-2013-r-w-sprawie-kryteriow-i-trybu-oceny-czasopism-naukowych/

2. http://www.nauka.gov.pl/europejska-karta-naukowca.

3. https://ori.hhs.gov/chapter-2-research-misconduct-office-science-and-technology-policy.

\section{FREEDOM OF CREATIVITY AND THE ALLEGATION OF AUTO PLAGIARISM IN A SCIENTIFIC WORK}

\begin{abstract}
Contemporary codes of values functioning in the area of science and concerning the authors of scientific works more frequently define auto plagiarism as an abuse on the part of the creator, aimed at evoking an untrue belief in the creativity and ingenuity of the creators. Is every reuse of creativity in a newly created work reprehensible from the point of view of both law and ethics? The content indicates the legal dependencies between the author and her work. Additionally, the constitutional meaning of creative freedom has been recalled, which in fact is understood as one of the basic rights being also present in the provisions of international acts. The following question has been posed: is this law unlimited? Arguments against the assumption that the freedom of creation possesses a ius absolutum character have been presented. Where to look for the author's limits of freedom in the context of civil power over the work? In the freedom and rights of other people as well as in the definition of a legal work, as elements being necessary to name an intellectual creation appear therein - in the sense of copyright law. The freedom of sciences is the foundation of every democratic order. However, is science, having an amazing power of influence on reality, subject to limitations? The article confirms such the thesis.
\end{abstract}

Keywords: auto plagiarism, plagiarism, author, scientific work, originality.

DOI: $10.7862 /$ rz.2018.hss.5

Przestano do redakcji: styczeń $2018 \mathrm{r}$.

Przyjęto do druku: kwiecień 2018 r. 